\title{
TRIGGERING EMERGENCY PROCEDURES: A CRITICAL OVERVIEW OF THE EU'S AND UN'S RESPONSE TO THE COVID-19 PANDEMIC AND BEYOND
}

\section{Nives Mazur-Kumrić, PhD, Assistant Professor}

Permanent Representation of the Republic of Croatia to the European Union Rue d'Arlon 108, 1000 Brussels, Belgium

Nives.Mazur-Kumric@mvep.hr

\section{Ivan Zeko-Pivač, PhD}

Permanent Representation of the Republic of Croatia to the European Union Rue d'Arlon 108, 1000 Brussels, Belgium

Ivan.Zeko-Pivac@mvep.hr

\begin{abstract}
The large-scale COVID-19 pandemic is a severe public health emergency which poses distressing social and economic challenges to the international community as a whole. In order to provide immediate and effective support to affected welfare and healthcare systems as well as to build their lasting, inclusive and sustainable recovery, both the European Union and the United Nations have introduced a number of urgent measures aiming to help and protect citizens and economies.
\end{abstract}

This paper looks into the specificities of urgent procedures launched and carried out by the two most influential international organisations with a view to rapidly respond to the unprecedented COVID-19 crisis. More specifically, it focuses on the involved institutions and steps of urgent procedures as well as on their most remarkable outcomes. In the case of the European Union, the emphasis is put primarily on two Coronavirus Response Investment Initiatives (CRIIs), adopted during the Croatian Presidency of the Council in one of the fastest legal procedures in the history of the European Union, and the Recovery Assistance for Cohesion and the Territories of Europe (REACT-EU) as an extension of the CRIIs' crisis repair measures. The overarching United Nations' response is assessed through an analysis of its urgent policy agenda developed on the premise that the COVID-19 pandemic is not only a health and socioeconomic emergency but also a global humanitarian, security and human rights crisis. This particularly includes procedures foreseen by the Global Humanitarian Response Plan (GHRP) and the Strategic Preparedness and Response Plan (SPRP). 
In addition, the aim of the paper is to provide a critical overview of the subject by highlighting three pivotal elements. First, the paper sheds light on the financial aspects of the urgent fight against the COVID-19 pandemic, necessary for turning words into action. Notably, this refers to funds secured by the Multiannual Financial Frameworks 2014-2020 and 2021-2027, and the Next Generation EU recovery instrument, on the one hand, and the UN COVID-19 Response and Recovery Fund, the UN Central Emergency Response Fund and the Solidarity Response Fund, on the other hand. Second, it offers a comparative evaluation of the end results of the European and global emergency procedures in mitigating the impacts of the COVID-19 pandemic. Finally, it summarises the underlying elements of measures governing the aftermath of the ongoing crisis, i.e. those promoting a human-centred, green, sustainable, inclusive and digital approach to future life.

Keywords: COVID-19 pandemic, emergency funding, European Union, United Nations, urgent procedures

\section{INTRODUCTION}

Since the onset of coronavirus disease 2019 (COVID-19) in December 2019, ${ }^{1}$ more than 2,800,000 people have died and 130,000,000 got infected worldwide. ${ }^{2}$ Apart from tragic human losses and enormous pressure on the healthcare and public health sector, ${ }^{3}$ the COVID-19 pandemic has rapidly led to a severe economic, social, humanitarian, human rights and environmental crisis. ${ }^{4}$ In consequence, the global health emergency has triggered introduction of a series of immediate response and recovery measures at local, national, regional and international level. They all underscore the long-standing precept that "crisis situations call for special measures",

$1 \quad$ Rutkow, L., Origins of the COVID-19 Pandemic and the Path Forward: A Global Public Health Policy Perspective, in: Brands, H.; Gavin, F. J. (eds.), COVID-19 and World Order: The Future of Conflict, Competition, and Cooperation, Johns Hopkins University Press, Baltimore, 2020, p. 107.

2 According to the regularly updated World Health Organization dashboard on COVID-19, there were 2,842,135 registered deaths and 130,422,190 confirmed cases as of 31 March 2021. The ten hardest hit countries include the USA, Brazil, India, France, Russia, the UK, Italy, Turkey, Spain and Germany. WHO Coronavirus (COVID-19) Dashboard, [https://covid19.who.int/], Accessed 3 April 2021.

3 What Will be the Impact of the COVID-19 Pandemic on Healthcare Systems?, Deloitte, Paris, June 2020.

4 Impact of the COVID-19 Pandemic on Trade and Development: Transitioning to a New Normal, UNCTAD/OSG/2020/1, 19 November 2020; The Impact of the COVID-19 Pandemic on Jobs and Incomes in G20 Economies, ILO-OECD paper prepared at the request of G20 Leaders Saudi Arabia's G20 Presidency 2020, ILO-OECD, 2020; Alawa, J. et al., Addressing COVID-19 in Humanitarian Settings: A Call to Action, Conflict and Health, Vol. 14, No. 1, 2020, pp. 1-4; Impact of the Coronavirus Disease (COVID-19) Pandemic on the Enjoyment of Human Rights Around the World, Including Good Practices and Areas of Concern, A/HRC/46/19, 18 January 2021; Prata, J. C. et al., COVID-19 Pandemic Repercussions on the Use and Management of Plastics, Environmental Science \& Technology, Vol. 54, No. 13, 2020, pp. 7760-7765.

5 Debates of the European Parliament (Mulder - ELDR, NL), Official Journal of the European Communities, No. 525-527, 9 October 1998, p. 298. 
which in the current state of affairs inevitably include the element of urgency. The character of special measures differs greatly from those aiming to flatten the curve ${ }^{6}$ to the ones defined to build long-term socioeconomic resilience. ${ }^{7}$

There is a growing body of legal literature examining and contextualising the effects of the COVID-19 pandemic and their countermeasures - from broader analyses of the preparedness rules codified in universal instruments ${ }^{8}$ to more focused assessments of particular regional ${ }^{9}$ and national ${ }^{10}$ approaches to the ongoing crisis. This paper provides a fresh comparative outlook on the latest emergency responses to the COVID-19 crisis at European and global level. Although earlier scholarly writings explore certain common aspects of the universal and European perspective on the pandemic, such as the precautionary principle, ${ }^{11}$ this research gives an original overarching insight into the most recent universal and European COVID-19 legislation and actions characterised by elements of urgency and financial upholding.

Thus, the following chapters examine the incidence and nature of urgency as a critical factor in recent procedures, tools, measures, action plans and funding schemes deployed by the two most influential international organisations - the European Union and the United Nations in addressing and mitigating the nega-

6 Santos, J.; Pagsuyoin, Sh., The Impact of "Flatten the Curve" on Interdependent Economic Sectors, in: Linkov, I.; Keenan, J. M.; Trump, B. D. (eds.), COVID-19: Systemic Risk and Resilience, Springer, Cham, 2021, pp. 163-181.

7 Trump, B. D.; Keenan, J. M.; Linkov, I., Multi-disciplinary Perspectives on Systemic Risk and Resilience in the Time of COVID-19, in: Linkov, I.; Keenan, J. M.; Trump, B. D. (eds.), COVID-19: Systemic Risk and Resilience, Springer, Cham, 2021, pp. 1-11; Siders, A. R.; Gerber-Chavez, L., Resilience for Whom? Insights for COVID-19 for Social Equity in Resilience, in: Linkov, I.; Keenan, J. M.; Trump, B. D. (eds.), COVID-19: Systemic Risk and Resilience, Springer, Cham, 2021, pp. 373-389; Wells, E. M. et al., Real-time Anticipatory Response to COVID-19, A Novel Methodological Approach, in: Linkov, I.; Keenan, J. M.; Trump, B. D. (eds.), COVID-19: Systemic Risk and Resilience, Springer, Cham, 2021, pp. 35-61.

8 De Guttry, A., Is the International Community Ready for the Next Pandemic Wave? A Legal Analysis of the Preparedness Rules Codified in Universal Instruments and of their Impact in the Light of the Covid-19 Experience, Global Iurist, Vol. 20, No. 3, 2020, pp. 1-41.

$9 \quad$ E.g. Van Schaik, L.; Jørgensen, K. E.; van de Pas, R., Loyal at Once? The EU's Global Health Awakening in the COVID-19 Pandemic, Journal of European Integration, Vol. 49, No. 8, 2020, pp. 1145-1160; Panebianco, S., Towards a Human and Humane Approach? The EU Discourse on Migration Amidst the COVID-19 Crisis, Italian Journal of International Affairs, Vol. 56, No. 2, 2021, pp. 19-37.

10 E.g. Bouhon, F. et al., L'État belge face à la pandémie de Covid-19: esquisse d'un régime d'exception, Courrier hebdomadaire, No. 2446, 2020, pp. 5-40; Menoni, S., Enhancing Current Practice from the Natural and Manmade Hazards Domain to Pandemic: Insights from the Italian Case, in: Linkov, I.; Keenan, J. M.; Trump, B. D. (eds.), COVID-19: Systemic Risk and Resilience, Springer, Cham, 2021, pp. 75-103.

11 The precautionary principle is a recognised legal principle in both International and European Law. It promotes the "better safe than sorry" approach and allows for the application of preventive measures even before a scientific consensus is reached. See: Meßerschmidt, K., COVID-19 Legislation in the Light of the Precautionary Principle, The Theory and Practice of Legislation, Vol. 8, No. 3, 2020, pp. 267-292. 
tive effects of the COVID-19 pandemic. With a view to providing immediate and effective support to affected welfare and healthcare systems as well as to building their lasting, inclusive and sustainable recovery, both the European Union and the United Nations have introduced a number of urgent measures aiming to help and protect citizens and economies. Given their numerousness and heterogeneity, the analysis is limited to the principal and systematic mechanisms that form the backbone of the international response to the COVID-19 pandemic.

The inquiry into the European Union's countermeasures puts emphasis on two Coronavirus Response Investment Initiatives (CRIIs), adopted during the Croatian Presidency of the Council of the European Union in one of the fastest legal procedures in the history of the European Union, and the Recovery Assistance for Cohesion and the Territories of Europe (REACT-EU) as an extension of the CRIIs' crisis response and repair measures. The comprehensive United Nations' response is assessed through examination of its urgent policy agenda developed on the premise that the COVID-19 pandemic is not only a health and socio-economic emergency but also a global humanitarian, security and human rights crisis. This particularly includes procedures foreseen by the Global Humanitarian Response Plan (GHRP) and the Strategic Preparedness and Response Plan (SPRP).

Introduction of adequate measures requires adequate funding, so the following chapters carefully link urgent actions with targeted sources of financing. In the event of the European Union, this refers to funds secured by the Multiannual Financial Frameworks 2014-2020 and 2021-2027, and the Next Generation $E U$ recovery instrument 2021-2023, while the United Nation's financial response encompasses the UN COVID-19 Response and Recovery Fund, the UN Central Emergency Response Fund and the Solidarity Response Fund.

The closing remarks of the analysis provide a consolidated assessment of the success of the measures introduced by the European Union and the United Nations and compare their scope, with a view to the anticipated uncertain process of socioeconomic recovery. Historically, both the European Union and the United Nations arose from crises and were significantly shaped thereby. As Ladi and Tsarouhas argue with respect to the European Union, "previous crises have led to incremental changes", which included the strengthening of current and introduction of new tools capable to respond to contemporary challenges. ${ }^{12}$ The same viewpoint is also

12 Ladi, S.; Tsarouhas, D., EU Economic Governance and COVID-19: Policy Learning and Windows of Opportunity, Journal of European Integration, Vol. 42, No. 8, 2020, pp. 1043-1044. On adaptation to crises and building resilience see also: Haldon, J. et al., Between Resilience and Adaptation: A Historical Framework for Understanding Stability and Transformation of Societies to Shocks and Stress, in: Linkov, I.; Keenan, J. M.; Trump, B. D. (eds.), COVID-19: Systemic Risk and Resilience, Springer, Cham, 2021, 
applicable to the United Nations. Our research confirms that, drawing on past experiences, the introduction of the COVID-19 crisis response and crisis repair measures by the European Union and the United Nations could be seen as, what Ladi and Tsarouhas call, "windows of opportunity" for future (socio) economic governance. ${ }^{13}$

\section{EUROPEAN UNION AND ITS URGENT RESPONSE TO THE COVID-19 PANDEMIC}

\subsection{In a Nutshell}

If at a specific moment circumstances, particular interests or needs in the European Union so require, the European Union's co-legislators may resort to a special procedure to bring legislation into force instead of employing the ordinary legislative procedure (OLP). ${ }^{14}$ The main characteristic of the OLP is adoption of legislation jointly and on an equal footing by the European Parliament and the Council of the European Union. ${ }^{15}$ In general, a legislative proposal - a regulation, a directive or a decision is presented by the European Commission and then debated in up to three readings whereat the two co-legislators may agree upon the joint text thereof. If they reach agreement, the procedure is thereby closed, at any reading. ${ }^{16}$ The internal legal acts of the co-legislators define possibilities on how to proceed with the urgent procedure. More specifically, the European Council, the Council of the European Union and the European Parliament define the possibility of using urgent procedures in their rules of procedure. The respective rules do not define how long the urgent procedure should last, but they determine steps that lead to a faster legislative procedure and entry into force of a legal act. In some

pp. 235-268.; Hynes, W. et al., Complexity, Interconnectedness and Resilience: Why a Paradigm Shift in Economics is Needed to Deal with COVID-19 and Future Shocks, in: Linkov, I.; Keenan, J. M.; Trump, B. D. (eds.), COVID-19: Systemic Risk and Resilience, Springer, Cham, 2021, pp. 61-75.

13 Ladi; Tsarouhas, ibid., p. 1041-1056.

14 The co-decision procedure for adopting EU legislation was first introduced in 1992. When the Treaty of Lisbon entered into force in 2009 , the term 'co-decision procedure' was replaced by 'ordinary legislative procedure'. In the ordinary legislative procedure, the two co-legislators are equal, which means that they both have a deciding vote or may amend a proposal in the legislative process. Loewenthal, P.-J., Articles 289-292, in: Kellerbauer, M.; Klamert, M.; Tomkin, J. (eds.), The EU Treaties and the Charter of Fundamental Rights - A Commentary, Oxford University Press, Oxford, 2019, p. 1912.

15 Consolidated Version of the Treaty on the Functioning of the European Union, OJ C 202, 7 June 2016, Article 289; Craig, P.; de Búrca, G., EU Law - Text, Cases, and Materials, Oxford University Press, Oxford, 2020, pp. 164-172; Schütze, R., An Introduction to European Law, Oxford University Press, Oxford, 2020, pp. 37-45.

16 Leino, P., The Politics of Efficient Compromise in the Adoption of EU Legal Acts, in: Cremona, M.; Kilpatrick, C., (eds.), EU Legal Acts: Challenges and Transformations, Oxford University Press, Oxford, 2018, pp. 30-70. 
circumstances, such as the COVID-19 pandemic, time can be crucial and special procedures are of particular importance.

The COVID-19 crisis was first recognised as a health crisis. Given the limited competence and legislative powers of the European Union in the field of health, there was an omnipresent fear that the common European response to a new health emergency would not be adequate. ${ }^{17}$ In addition, the EU Member States were rather uncoordinated in supporting and funding their own global health priorities before the COVID-19 pandemic..$^{18}$ However, the following chapters on specific cases of the EU's urgent actions demonstrate the ability of the European Union to flexibly respond to an unprecedented health situation with a set of effective measures which successfully combine urgent interventions in the health sector with those in economy and labour rights. This conclusion is in line with what Wolff and Ladi described as a proven "degree of (the EU's) adaptability to a 'permanent' emergency mode". ${ }^{19}$

Before thoroughly examining the latest urgent measures introduced by the European Union amidst the ongoing COVID-19 crisis, the following chapter offers a brief overview of the rules of procedure regulating possible urgent steps of three EU instances: the European Council, the Council of the European Union and the European Parliament.

\subsection{Rules of Procedure}

\subsubsection{European Council}

According to Article 7 of the Rules of Procedure of the European Council, "Decisions of the European Council on an urgent matter may be adopted by a written vote where the President of the European Council proposes to use that procedure. Written votes may be used where all members of the European Council having the right to vote agree to that procedure." ${ }^{20}$ In other words, the respective rule allows the co-legislator to opt for an emergency procedure when consent can be effectively obtained in writing. The General Secretariat of the Council regularly

17 See more: Delhomme, V., Emancipating Health from the Internal Market: For a Stronger EU (Legislative) Competence in Public Health, European Journal of Risk Regulation, Vol. 11, No. 4, 2020, pp. 747-756.

18 Van Schaik; Jørgensen; van de Pas, op. cit., note 9, pp. 1146; Beaussier, A.-L.; Cabane, L., Strengthening the EU's Response Capacity to Health Emergiencies: Insights from EU Crisis Management Mechanisms, European Journal of Risk Regulation, Vol. 11, No. 4, 2020, p. 808.

19 Wolff, S.; Ladi, S., European Union Responses to the COVID-19 Pandemic: Adaptability in Times of Permanent Emergency, Journal of European Integration, Vol. 42, No. 8, 2020, pp. 1025-1040.

20 European Council Decision of 1 December 2009 adopting its Rules of Procedure, OJ L 315, 2 December 2009. 
prepares a summary of acts adopted within the written procedure. ${ }^{21}$ The European Council, as the highest instance of political decision-making, does not take part in every urgent legislative process and acts only on issues of the highest political importance.

\subsubsection{Council of the European Union}

The urgent steps of the Council of the European Union are regulated by Article 12 of the Rules of Procedure of the Council of the European Union on ordinary written procedure and silence procedure. Its paragraph 1 stipulates that "Acts of the Council on an urgent matter may be adopted by a written vote where the Council or Coreper unanimously decides to use that procedure. In special circumstances, the President may also propose the use of that procedure; in such a case, written votes may be used where all members of the Council agree to that procedure." ${ }^{22}$ Furthermore, paragraph 1 also specifies that "Agreement by the Commission to the use of the written procedure shall be required where the written vote is on a matter which the Commission has brought before the Council". ${ }^{23}$ In accordance with paragraph 2 of the same Article, "On the initiative of the Presidency, the Council may act by means of a simplified written procedure called 'silence procedure"', whereby the provision lists the cases in which the Council may resort to the silence procedure. ${ }^{24}$

\subsubsection{European Parliament}

The $9^{\text {th }}$ parliamentary term of the European Parliament is underway (2019-2024), and its Rules of Procedure were updated accordingly in December 2019.25 The relevant provision of the Rules of Procedure regulating the urgent procedure is Rule 163, which explains in detail who can launch the procedure and how it is handled. Paragraph 1 thereof stipulates that "A request to treat a debate on a proposal submitted to Parliament pursuant to Rule $48(1)^{26}$ as urgent may be made to Parliament by the President, a committee, a political group, Members reaching at least the low threshold, the Commission or the Council. Such requests shall be

\footnotetext{
$21 \quad$ Ibid.

22 Council Decision of 1 December 2009 adopting the Council's Rules of Procedure, OJ L 325,11 December 2009.

23 Ibid.

24 Ibid.

25 Rules of Procedures, European Parliament 2019-2024 - $9^{\text {th }}$ Parliamentary Term, European Parliament, January 2021, pp. 93-94.

26 Ibid., p. 36 . Rule 48 relates to 'Consideration of legally binding acts'.
} 
made in writing and supported by reasons." ${ }^{27}$ Furthermore, paragraph 2 of the same Rule states that "As soon as the President has received a request for urgent debate this shall be announced in Parliament. The vote on the request shall be taken at the beginning of the sitting following that during which the announcement was made, provided that the proposal to which the request relates has been distributed to Members in the official languages. Where there are several requests for urgent debate on the same subject, the approval or rejection of the request for urgent debate shall apply to all such requests that are on the same subject." ${ }^{28}$ In addition, Rule 163 clarifies who can speak during a hearing under the accelerated procedure and under what conditions. According to paragraph 3 thereof, "Before the vote, only the mover, and one speaker against may be heard, along with the Chair or rapporteur of the committee responsible, or both. None of those speakers may speak for more than three minutes". ${ }^{29}$ In its paragraph 4, Rule 163 specifies that "Questions to be dealt with by urgent procedure shall be given priority over other items on the agenda". Finally, paragraph 5 accentuates that "An urgent procedure may be held without a report or, exceptionally, on the basis of an oral report by the committee responsible." 30

\subsection{Specific Cases of Urgent Procedures Triggered by the COVID-19 Pandemic with Special Emphasis on Cohesion Policy}

\subsubsection{Coronavirus Response Investment Initiative (CRII)}

In order to contribute to the introduction of suppression measures related to the COVID-19 pandemic and limit its negative socio-economic impact on the European Union as a whole, the European Commission published the Communication 'Coordinated Economic Response to the COVID-19 Outbreak' on 13 March 2020. ${ }^{31}$ Accompanied by three Annexes, the Communication launched a special investment initiative - Coronavirus Response Investment Initiative (CRII), to respond to COVID-19 with a particular package of measures which mobilises the existing liquidity of 8 billion euros under the Structural Funds of the European Union. This amount should trigger additional 29 billion euros of EU's cofinancing from structural funding across the Member States, which would result in up to 37 billion euros directed into public investment to fight the COVID-19

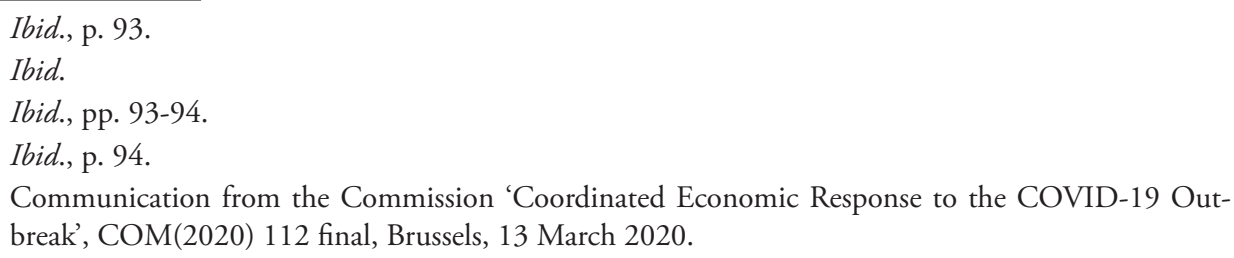


pandemic. ${ }^{32}$ The package of measures is specifically defined in two new legislative proposals: (1) Proposal for a Regulation amending the following Regulations of the current financial period (2014-2020) - the Common Provisions Regulation (CPR), the European Regional Development Fund (ERDF) Regulation and the European Maritime and Fisheries Fund (EMFF) Regulation, for the purpose of introducing specific measures to mobilise investments in the health care systems of the Member States and in other sectors of their economies in response to the COVID-19 outbreak, ${ }^{33}$ and (2) Proposal for a Regulation amending the Regulation on the EU Solidarity Fund, for the purpose of providing financial assistance to the Member States and countries negotiating their accession to the Union seriously affected by a major public health emergency. ${ }^{34}$ Both Proposals were urgently presented and discussed within the Council of the European Union just four days after their publishing, i.e. at the meeting of the Working Party on Structural Measures (SMWP), held on 17 March 2020. The legislative package was adopted by the European Parliament already on 26 March 2020 and by the Council on 30 March 2020, and entered into force on 1 April 2020. This means that only 19 days passed from the day of the CRII's presentation to the entry into force of the package. ${ }^{35}$

In particular, the European Commission proposed to waive the obligation to request reimbursement of unused pre-financing for the European Structural and Investment Funds (ESIF) in 2020. This refers to the above-mentioned amount of 8 billion euros from the EU budget, which is additionally supplemented by up to 29 billion euros of unallocated Structural Funds from existing national envelopes to combat the crisis caused by the COVID-19 pandemic. The key element of the CRII is the rule that all potential expenditure to combat COVID-19 shall be eligible for funding from the Structural Funds from 1 February 2020. In addition, the European Commission also proposed the possibility of a significant transfer of funds within a programme in a simplified way. These measures allow the Member States to channel funds into support of their health systems, liquidity of

$32 \quad$ Ibid., p. 7.

33 Proposal for a Regulation of the European Parliament and of the Council amending Regulation (EU) No 1303/2013, Regulation (EU) No 1301/2013 and Regulation (EU) No 508/2014 as regards specific measures to mobilise investments in the health care systems of the Member States and in other sectors of their economies in response to the COVID-19 outbreak, COM (2020) 113 final, Brussels, 12 March 2020.

34 Proposal for a Regulation of the European Parliament and of the Council amending Council Regulation (EC) No 2012/2002 in order to provide financial assistance to Member States and countries negotiating their accession to the Union seriously affected by a major public health emergency, COM2020 114 final, Brussels, 12 March 2020.

35 This is the internal information of the Structural Measures Working Party (SMWP) of which the co-authors are members. 
companies, and flexible working schemes as well as of upskilling and reskilling of workers. As part of the CRII, the European Commission also proposed to extend the scope of the EU Solidarity Fund (EUSF) to include the public health crisis. Around 800 million euros was made available for this purpose in 2020. Finally, the European Globalization Adjustment Fund (EGAF) was mobilized to support dissmissed workers and the self-employed with the allocation of around 179 million euros in $2020 .^{36}$

\subsubsection{Coronavirus Response Investment Initiative Plus (CRII+)}

Since the negative socio-economic effects of the COVID-19 pandemic became more prominent after the adoption of the CRII's legislative package, the European Commission published, as soon as of 2 April 2020, a new Communication titled 'Responding to the Coronavirus - Using Every Available Euro in Every Way Possible to Protect Lives and Livelihoods'. ${ }^{37}$ The legislative package, known as 'Coronavirus Response Investment Initiative Plus' (CRII+), proposed a set of measures in the area of Cohesion Policy to provide additional flexibility for the use of the European Investment and Structural Funds in response to the COVID-19 pandemic. Thus, a new legal basis for the regulation of this issue has become the Proposal for a Regulation of the European Parliament and of the Council amending Regulation (EU) no. 1303/2013 and Regulation (EU) no. 1301/2013 with regard to special measures to ensure exceptional flexibility for the use of the European Investment and Structural Funds in response to the outbreak of COVID-19. ${ }^{38}$

The CRII+ was designed to ensure support to citizens and liquidity of the financial sector, with particular emphasis on supporting small and medium-sized enterprises (SMEs). It was assumed that the GDP growth of the European Union would fall to zero or even below zero in 2020 due to the pandemic, so a coordinated economic response of the European Union's institutions and Member States was crucial to save lives and provide funds for the protection of the worstaffected workers and SMEs. A new, temporary instrument named 'Support to mitigate Unemployment Risks in an Emergency' (SURE) and worth 100 billion euros was proposed in the form of loans to the hardest hit countries mostly to help workers retain wages and help employers retain workers. In addition, the Euro-

36 Communication from the Commission, op. cit., note 31, pp. 7-8.

37 Communication from the Commission 'Coronavirus Response - Using Every Available Euro in Every Way Possible to Protect Lives and Livelihoods', COM (2020) 143 final, Brussels, 2 April 2020.

38 Proposal for a Regulation of the European Parliament and of the Council amending Regulation (EU) No 1303/2013 and Regulation (EU) No 1301/2013 as regards specific measures to provide exceptional flexibility for the use of the European Structural and Investments Funds in response to the COVID-19 outbreak, COM/2020/138 final, Brussels, 2 April 2020. 
pean Commission proposed some modifications related to the Fund for European Aid to the Most Deprived (FEAD) in terms of introduction of new delivery methods, such as electronic vouchers and purchase of protective equipment, in order to protect volunteers who deliver aid from getting infected by COVID-19. As farmers and the fisheries sector, who are severely affected by the health crisis, are central to food security across the EU, the European Commission also proposed flexible measures within the European Maritime and Fisheries Fund (EMFF) and the Common Agricultural Policy (CAP) to help them overcome the crisis. The CRII Plus enables mobilising all the unused funds of Cohesion Policy 2014-2020 (which includes the European Regional Development Fund - ERDF, the European Social Fund - ESF and the Cohesion Fund - CF) and maximum flexibility in their transfers. A great novelty introduced by the CRII+ is that no national cofinancing will be requested for any of the funds. What was also proposed is that there are no restrictions when it comes to thematic concentration. With the aim of easing the administrative burden, the Member States will be exempted from the requirement to amend Partnership Agreements, the deadline for the submission of annual reports will be postponed and some flexibility was introduced when closing the programme. ${ }^{39}$

Soon after its introduction on 2 April 2020, the CRII+ was adopted by the European Parliament on 17 April and the Council of the European Union on 24 April 2020. The initiative came into force soon afterwards, on 24 April 2020, which was only 23 days after its presentation. This means that it took less than a month for both the CRII and the CRII+ to enter into force, which is considered as one of the fastest legal procedures in the history of the European Union..$^{40}$

\subsubsection{Recovery Assistance for Cohesion and the Territories of Europe (REACT- $E U)$}

The Recovery Assistance for Cohesion and the Territories of Europe (REACTEU) was introduced on 28 May 2020 as an extension of the CRIIs' crisis response and repair measures in the domain of Cohesion Policy. ${ }^{41}$ Cohesion Policy is the European Union's main investment policy, which plays a major role in ensuring "a

39 Communication from the Commission, op. cit., note 37, pp. 2-6.

40 This is the internal information of the Structural Measures Working Party (SMWP) of which the co-authors are members.

41 Regulation (EU) 2020/2221 of the European Parliament and of the Council of 23 December 2020 amending Regulation (EU) No 1303/2013 as regards additional resources and implementing arrangements to provide assistance for fostering crisis repair in the context of the COVID-19 pandemic and its social consequences and for preparing a green, digital and resilient recovery of the economy (REACT-EU), OJ L 437, 28 December 2020. 
balanced recovery, fostering convergence and making sure no one is left behind" during and after the COVID-19 pandemic. ${ }^{42}$ The global health emergency has led to the closure of companies and introduction of numerous restrictions in the Member States, which in turn has led to a significant decline in economic activity and severe social degradation. In order to prevent further widening of disparities and avoid uneven recovery, the European Commission proposed, with the introduction of the REACT-EU, to provide additional funding to the European Structural and Investment Funds (ESIF) for 2020, 2021 and 2022 in the amount of more than 58 million euros in current prices. This funding is completely fresh, it is a top up to 2014-2020 programmes and additional to the Cohesion Policy allocations 2021-2027.43

The REACT-EU complements the previously adopted CRIIs' amendments, which introduce special measures to mobilise investment in health care and economic systems in order to respond to the COVID-19 pandemic. The initiatives also offer appertaining special measures to provide exceptional flexibility for the use of the European Structural and Investment Funds. In this context, the European Commission has proposed to use the full potential of the EU budget to mobilise investment and financial support in the first years of recovery. Successful implementation of the REACT-EU is highly dependent on three building blocks "its strength (financial allocation), speed (by using the existing programmes until 2023) and full flexibility of the implementation rules". ${ }^{44}$ The financial scheme is based on two pillars - the European Recovery Instrument worth 750 billion euros (of which the REACT-EU is part) and the strengthened Multiannual Financial Framework (MFF) 2021-2027. Additional funding will also be distributed to the Member States from the European Regional Development Fund (ERDF), the European Social Fund (ESF) and the Fund for European Aid to the Most Deprived (FEAD) in 2021 and 2022. The distribution should support crisis management operations in the context of the COVID-19 pandemic in regions whose economies are severely hit thereby and are thus undergoing the process of preparing a green, digital and resilient recovery. ${ }^{45}$

The REACT-EU Regulation was adopted on 23 December 2020 and came into force on 1 January $2021 .{ }^{46}$ Although the REACT-EU had all the preconditions to be adopted by a fast-track, urgent procedure, the co-legislators decided to make

\footnotetext{
42 REACT-EU, [https://ec.europa.eu/regional_policy/en/newsroom/coronavirus-response/react-eu], Accessed 8 March 2021.

43 Ibid.

44 Ibid.

45 Ibid.

46 Regulation (EU) 2020/2221, loc. cit. note 41.
} 
changes to the European Commission's proposal, which made the legislative process longer. Nevertheless, the adoption of the REACT-EU was much faster than the adoption of other legislative acts of the Cohesion Policy legislative package 2021-2027, the adoption of which required nearly three-year negotiations. It is important to note that the REACT-EU has enabled allocation of separate funding for the measures first envisaged by the CRIIs and then by the REACT-EU as a guarantee of an effective fight against the consequences of the COVID-19 pandemic.

\section{UNITED NATIONS AND ITS URGENT RESPONSE TO THE COVID-19 PANDEMIC}

\subsection{In a Nutshell}

On 25 June 2020, the UN released the first comprehensive overview of its urgent response to COVID-19, ${ }^{47}$ soon followed by the second edition in September $2020,{ }^{48}$ highlighting the main pillars, actors, priorities, policies and funding sources of its overarching approach to the global health emergency. The two reports of utmost relevance for understanding the UN's approach to the COVID-19 crisis shed light on the fragility and inequality of our societies, accentuated by the pandemic and call for "a whole-of-society, whole-of-government and whole-ofthe-world approach driven by compassion and solidarity". ${ }^{49}$

The United Nations response to the COVID-19 pandemic is structured around four principal objectives, similar to those of the EU: delivering an all-inclusive global response that leaves no one behind; reducing the level of vulnerability to future pandemics; building resilience to future shocks (esp. climate change); and overcoming severe and systemic inequalities revealed and potentiated by the pandemic. These objectives are achieved through three types of operations, depending on whether the response addresses health aspects; socioeconomic, humanitarian and human rights aspects; or recovery aspects of the crisis. ${ }^{50}$

The following chapters outline three distinctive modes of intervention employed by the United Nations to effectively deal with the consequences of the unprecedented COVID-19 pandemic and to set up a legal and socio-economic framework for post-

\footnotetext{
47 United Nations Comprehensive Response to COVID-19: Saving Lives, Protecting Societies, Recovering Better, United Nations, New York, June 2020.

48 United Nations Comprehensive Response to COVID-19: Saving Lives, Protecting Societies, Recovering Better, United Nations, New York, September 2020.

49 Ibid., p. 6.

50 United Nations Comprehensive Response to COVID-19, op. cit., note 47, pp. 5-6, 12-14.
} 
pandemic resilience. First, the nature and role of the Special Procedures of the Human Rights Council in addressing the impact of the COVID-19 on human rights are thoroughly explained. Second, the features of two response plans - the Global Humanitarian Response Plan (GHRP) and the Strategic Preparedness and Response Plan (SPRP) are summarised. Finally, the last chapter looks into the financial aspects necessary to turn the United Nations' words into action, bringing attention to three funding sources - the UN COVID-19 Response and Recovery Fund, the UN Central Emergency Response Fund and the Solidarity Response Fund.

The nature of this paper limits the examination of the United Nations' actions to those with a high urgency factor only. Yet, it is essential to underline that the United Nation's activities related to the pandemic have been much more numerous, diverse and varied. Some fine examples of scholarly discourses elaborating these UN's interventions include de Guttry's broad investigation into the specificities pertinent to UN documents on major health issues and managing related disasters ${ }^{51}$ and Cormacain's brief overview of some UN documents falling under the category of emergency legislation (as distinct from ordinary legislation). ${ }^{52}$

\subsection{Modalities of the United Nations Urgent Interventions in Response to COVID-19}

\subsubsection{Special Procedures of the Human Rights Council}

\section{a) General Overview}

The 2008 Manual of Operations of the Special Procedures broadly describes the system of the Special Procedures of the Human Rights Council as "a diverse range of procedures established to promote and protect human rights and to prevent violations in relation to specific themes or issues, or to examine the situation in specific countries". ${ }^{53}$ It is considered as the central element of the United Nations

51 De Guttry, op. cit., note 8, pp. 8-14, 19.

52 Cormacain, R., Keeping COVID-19 Emergency Legislation Socially Distant from Ordinary Legislation: Principles for the Structure of Emergency Legislation, The Theory and Practice of Legislation, Vol. 8, No. 3, 2020, pp. 249-251.

53 Manual of Operations of the Specific Procedures of the Human Rights Council, Human Rights Council, New York, August 2008, p. 4. The system is primarily derived from the practice of the Commission of Human Rights, the establishment of which dates back to 1967. The current mechanism reflects the change in the UN human rights machinery, made in 2006 when the Human Rights Council replaced the Commission of Human Rights. Its legal basis was set out in 2007 by the Resolution 5/1 of the Human Rights Council on Institution-building of the United Nations Human Rights Council and Resolution 5/2 of the Human Rights Council on the Code of Conduct for Special Procedures Mandate-holders of the Human Rights Council. See: Report to the General Assembly on the Fifth Session of the Council, A/HRC/5/21, 7 August 2007; Mazur-Kumrić, N.; Komanovics, A., The Human Rights 
human rights scheme ${ }^{54}$ and as "the eyes and ears of the Human Rights Council". 55 During the COVID-19 pandemic, the Special Procedures have proved to be one of the backbones of the United Nations system for an urgent response to the crisis.

The Special Procedures is a term which specifically denotes independent UN human rights experts accountable to the Human Rights Council and mandated to carry out investigations on the allegations of human rights violations in all parts of the world ${ }^{56}$. Apart from investigating, their mandate also includes issuing recommendations on a particular thematic issue (thematic mandates) or country situation (country-specific mandates), which take full account of all human rights: civil, political, economic, social and cultural ${ }^{57}$. In addition, in their effort to adequately protect the victims or potential victims of human rights violations, their activities may include communicating information through letters of allegations or urgent appeals, issuing related recommendations and conclusions, country visits, thematic studies etc..$^{58}$ The interventions of the Special Procedures directed to Governments and other stakeholders (non-state actors) in the form of letters (urgent appeals, allegation letters, and other communications) may touch upon three types of human rights violations: one that has already taken place, one that is ongoing, and one with a high risk of taking place. Their subject may range from individual cases concerning one individual/one particular group to general examples of human rights abuses. ${ }^{59}$

The Special Procedures are also called mandate-holders and may be either an individual ("Special Rapporteur" or "Independent Expert") or a Working Group of five members representing the five UN regional groups (Africa, Asia and the Pacific, Eastern Europe, Latin America and the Caribbean, and the Western Europe and Others), "Special Representative of the Secretary General" and "Representative of the Secretary-General". ${ }^{60}$ Regardless of their different titles, their responsibilities and methods of work are the

Council and the Universal Periodic Review: A Novel Method of Promoting Compliance with Human Righs, in: Drinóczi, T. et al. (eds.), Contemporary Legal Challenges: EU - Hungary - Croatia, Faculty of Law, University of Pécs/Faculty of Law, J. J. Strossmayer University of Osijek, 2012, pp. 641-671.

54 Directory of Special Procedures Mandate Holders, HRC/NONE/2017/74/Rev.3/iPub, July 2020.

55 Subedi, S. P., Protection of Human Rights through the Mechanism of UN Special Rapporteurs, Human Rights Quarterly, Vol. 33, No. 1, 2011, p. 204.

56 Manual of Operations of the Specific Procedures of the Human Rights Council, op. cit., note 53, p. 5.

57 Ibid.

58 Ibid., pp.14-26.

59 Mandates of the Special Rapporteur on the human rights of migrants et al., UA OTH 87/2020, 15 January 2021, p.1.

60 Manual of Operations of the Specific Procedures of the Human Rights Council, op. cit., note 53, pp. $5-7$. 
same or very similar. ${ }^{61}$ It is important to note that they neither represent quasi-judicial mechanisms nor affect national judicial procedures ${ }^{62}$. As of 1 November 2020, there were 44 thematic and 11 country mandates with 79 mandate holders. ${ }^{63}$

\section{b) Urgent Appeals}

In exercising their functions at the time of the COVID-19 pandemic, the Special Procedures resort to a particular type of urgent procedures - urgent appeals. Pursuant to Article 10 of the Code of Conduct for Special Procedures Mandateholders of the Human Rights Council, "mandate-holders may resort to urgent appeals in cases where alleged violations are time-sensitive in terms of involving loss of life, life-threatening situations or either imminent or ongoing damage of a very grave nature to victims that cannot be addressed in a timely manner by the procedure of Article 9 of the present Code". ${ }^{64}$ For example, the Special Rapporteur on the negative impact of unilateral coercive measures transmitted an urgent appeal to the Government of the United States of America for their trade embargo against Cuba, due to which the medical equipment donated by a Chinese entrepreneur for the purpose of fighting the pandemic could not be transferred to Cuba. ${ }^{65}$ Another urgent appeal to the United States of America, prepared jointly by eight mandate-holders, threw light on the grave conditions of 819 migrant women confined at the Irwin County Detention Centre. It concerns the lack of appropriate protection measures during the COVID-19 pandemic since March 2020 onwards, but also a number of other alleged human rights abuses, additionally aggravated by the pandemic, such as the lack of access to healthcare, ill-treatment and medical-abuses (e.g. unwarranted gynaecological surgeries). ${ }^{66}$ In both

${ }_{61}$ Manual of Operations of the Specific Procedures of the Human Rights Council, ibid., p. 6, note 5; Review of the Work and Functioning of the Human Rights Council, A/HRC/RES/16/21, 12 April 2011, points 23-30.

62 Manual of Operations of the Specific Procedures of the Human Rights Council, ibid., p. 14.

63 Current and Former Mandate-Holders for Existing Mandates Valid as of 1 November 2020, [https:// www.ohchr.org/EN/HRBodies/SP/Pages/Currentmandateholders.aspx], Accessed 8 February 2021.

64 Code of Conduct for Special Procedures Mandate-holders of the Human Rights Council, A/ HRC/5/21, 7 August 2007. Article 9 of the respective Code regulates Letters of Allegation, which are regarded as standard communication tools used by the Special Procedures in their usual interaction with Governments, intergovernmental organisations, businesses, security or military companies etc. when it is alleged that human rights violations have already occurred and or in other cases when urgent procedures are not applicable. See: Manual of Operations of the Specific Procedures of the Human Rights Council, op. cit., note 53, p. 15.

65 Report of the Special Rapporteur on the negative impact of unilateral coercive measures on the enjoyment of human rights - Negative impact of unilateral coercive measures on the enjoyment of human rights in the coronavirus disease pandemic, A/75/209, 21 July 2020, p. 7.

66 Mandates of the Special Rapporteur et al., loc. cit., note 59. 
cases, the American Government was asked to provide additional information on the allegations, indicate specific measures, actions and steps taken to adequately protect violated human rights, and urgently take all necessary interim measures "to halt the alleged violations and prevent their re-occurrence and in the event that the investigations support or suggest the allegations to be correct, to ensure the accountability of any person responsible of the alleged violations". ${ }^{67}$

\section{c) Other Communicating Tools with Urgent Elements - Thematic Reports in Focus}

The Special Procedures have been greatly employed in the United Nations' efforts to effectively respond to the pandemic. The modes of employment have been varied, spanning from recommendations to States and other stakeholders to reports to the Human Rights Council and the General Assembly. Their main feature is application of a human rights approach in addressing the consequences of the COVID-19 crisis. $^{68}$ More specifically, in March 2020, over 60 mandate-holders launched a general call pointing out that "everyone has the right to life-saving interventions" and that the crisis cannot be approached solely from the public health and emergency perspective but from the human rights one as well. They also called for application of "the principles of non-discrimination, participation, empowerment and accountability" in all health-related policies. ${ }^{69}$ In addition, mandate-holders issued 14 guidance tools as well as sent 287 communications to State and non-State actors in less than a year (i.e. from the beginning of the pandemic until late January 2021). ${ }^{70}$ In the same short period, they presented 15 reports to Human Rights Council and/or the General Assembly while three more are expected in 2021..$^{71}$ Those reports are another crucial tool for the United $\mathrm{Na}$ tion's urgent response to the COVID-19 as they regularly and repeatedly call for urgent actions to ensure that all human rights are protected during the pandemic. For example, the Special Rapporteur on violence against women called in her report for urgent action to protect women from gender-based violence and domestic violence during the pandemic. ${ }^{72}$

\footnotetext{
67 Ibid., p. 14.

68 Special Procedures and Covid-19, United Nations Human Rights Special Procedures, New York, 22 January 2021.

69 Pūras, D. et al., The Right to Health Must Guide Responses to COVID-19, The Lancet, Vol. 395, No. 10241, 2020, p. 1890, note 12.

70 Special Procedures and Covid-19, loc. cit., note. 68.

71 Ibid.

72 Report of the Special Rapporteur on violence against women, its causes and consequences - Intersection between the coronavirus disease (COVID-19) pandemic and the pandemic of gender-based
} 
To underline the importance and variety of the topics covered in COVID-19 thematic reports as a critical pillar of today's human rights protection, some of their central messages are summarised below. The reports provide guidance and recommendations with regard to diverse human rights seriously affected by the pandemic. Specifically, the Special Rapporteur on extreme poverty shed light on the severely disadvantaged position of persons in extreme poverty and the need for their adequate social protection in the post-COVID-19 economic recovery in line with human rights standards. This especially concerns vulnerable people employed in the informal sector and in precarious forms of employment, such as migrants, indigenous peoples and women. ${ }^{73}$ The Special Rapporteur on the negative impact of unilateral coercive measures presented the repercussions of unilateral sanctions (such as trade and arms embargoes and travel restrictions) imposed by the United States, the European Union and the United Kingdom on the ability of sanctioned countries to deal with the pandemic, especially in terms of the enjoyment of human rights and delivery of humanitarian aid. She recommended assessment of unilateral sanctions imposed without authorisation of the Security Council and humanitarian exemptions for trade in essential humanitarian goods and commodities. ${ }^{74}$ The Independent Expert on foreign debt and human rights addressed the interrelation between the financial obligations of low-income and developing countries at the time of the pandemic and the right of their citizens to fully enjoy their economic, social, cultural and other rights. Since debt undermines a country's emergency response efforts and potentiates the rapid rise of inequality, poverty and marginalisation, she recommended emergency financing, fiscal stimulus packages, temporary debt standstill or debt restructuring and cancellation. ${ }^{75}$ Particularly important is the report of the Special Rapporteur on the right to education, which stresses that more than 1.5 billion learners all around the world were negatively affected by the closure of educational institutions, calling for, inter alia, in-depth assessments of these restrictions and introduction of the "4As" system of

violence against women, with a focus on domestic violence and the "peace in the home" initiative, A/75/144, 24 July 2020, p. 7.

73 Looking Back to Look Ahead: A Rights-based Approach to Social Protection in the Post-COVID-19 Economic Recovery, Special Rapporteur on extreme poverty and human rights, United Nations Human Rights Special Procedures, New York, 11 September 2020, pp. 1-2, 4, 10-14, 20-25.

74 Report of the Special Rapporteur on the negative impact of unilateral coercive measures on the enjoyment of human rights, op. cit., note. 65 .

75 Report of the Independent Expert on the effects of foreign debt and other related international financial obligations of States on the full enjoyment of all human rights, particularly economic, social and cultural rights - Addressing the COVID-19 Debt related Problems of Developing Countries from a Human Rights perspective, A/75/164, 31 July 2020, p. 2. 
education at all levels (Availability, Accessibility, Acceptability and Adaptability). ${ }^{76}$ The most anticipated report was certainly the one prepared by the Special Rapporteur on the right to health, which analyses the interrelatedness between the right to health and other human rights, particularly civil and political ones. ${ }^{77}$ The report of the Special Rapporteur on the right to privacy also received much attention due to privacy-intrusive anti-COVID-19 measures such as surveillance and contact tracing. Although extraordinary situations require extraordinary measures, the Special Rapporteur concluded that every State is obliged to pay particular attention to the principles of necessity and proportionality. ${ }^{78}$ One of the most sensitive reports was the one prepared by the Special Rapporteur on Freedom of Opinion and Expression. It points out five challenges that a society may encounter during pandemics: access to information held by public authorities, access to the Internet, protection and promotion of independent media, public health disinformation and public health surveillance. ${ }^{79}$ The COVID-19 pandemic has brought the culture sector to a dangerous standstill, which the Special Rapporteur on cultural rights described as "a cataclysm for cultural rights". In her conclusions and recommendations, she called for urgent action to guarantee these rights as they are "central to human well-being, resilience and development". ${ }^{80}$ Lockdowns, teleworking and online schooling have put the Special Rapporteur on adequate housing in the spotlight. In his report, he advocated for the right to adequate housing in line with the principle of non-discrimination, enforcement of a moratorium on evictions and foreclosures, improvement of social protection measures and many other actions. ${ }^{81}$ The Special Rapporteur on hazardous substances and waste put the duty of every State to prevent exposure to the COVID-19 virus in the focus of his report, summing up zoonotic viruses under hazardous substances. ${ }^{82}$

76 Report of the Special Rapporteur on the right to education - Right to education: impact of the COVID-19 crisis on the right to education; concerns, challenges and opportunities, A/HRC/44/39, 15 June 2020, p. 4.

77 Final report of the Special Rapporteur on the right of everyone to the enjoyment of the highest attainable standard of physical and mental health, A/75/163, 16 July 2020, p. 15-22.

78 Report of the Special Rapporteur on the right to privacy, A/75/147, 27 July 2020, pp. 2, 17-18.

79 Report of the Special Rapporteur on the promotion and protection of the right to freedom of opinion and expression - Disease pandemics and the freedom of opinion and expression, A/HRC/44/49, 23 April 2020, pp. 2.

80 Report of the Special Rapporteur in the field of cultural rights - COVID-19, culture and cultural rights, A/HRC/46/34, 17 February 2021, pp. 4-10, 19-21.

81 Report of the Special Rapporteur on adequate housing as a component of the right to an adequate standard of living, and on the right to non-discrimination in this context - COVID-19 and the right to adequate housing: impacts and the way forward, A/75/148, 27 July 2020, pp. 21-22.

82 Report of the Special Rapporteur on the implications for human rights of the environmentally sound management and disposal of hazardous substances and wastes - Duty to prevent exposure to the COVID-19 virus, A/HRC/45/12, 13 October 2020, p. 21. 
Various examples of the adverse impact of the COVID-19 pandemic on particular groups of people or entities were also addressed by the Special Rapporteur on violence against women, ${ }^{83}$ the Independent Expert on Sexual Orientation and Gender Identity, ${ }^{84}$ the Independent Expert on older persons, ${ }^{85}$ the Working Group on the Peoples of African Descent, ${ }^{86}$ the Special Rapporteur on the Sale and sexual exploitation of children, ${ }^{87}$ the Special Rapporteur on the Rights of Indigenous Peoples, ${ }^{88}$ the Special Rapporteur on the elimination of discrimination against persons affected by leprosy and their family members ${ }^{89}$ and the Special Rapporteur on Contemporary Forms of Slavery. ${ }^{90}$

\subsubsection{Urgent Response Plans of the United Nations}

\section{a) Global Humanitarian Response Plan (GHRP)}

At the very outset of the COVID-19 pandemic, the United Nations launched a comprehensive 10.3-billion-dollar worth Global Humanitarian Response Plan to help 63 low-income countries deal with direct and indirect impacts of COVID-19 ${ }^{91}$. That coordinated operation, targeting around 250 million most vulnerable people, was introduced in March 2020 for the purpose of covering expenses related to essential health services and many other immediate multi-sectoral

83 Report of the Special Rapporteur on violence against women, its causes and consequences, op. cit., note 72.

84 Report of the Independent Expert on protection against violence and discrimination based on sexual orientation and gender identity - Violence and discrimination based on sexual orientation and gender identity during the coronavirus disease (COVID-19) pandemic, A/75/258, 28 July 2020.

85 Report of the Independent Expert on the enjoyment of all human rights by older persons - Impact of the coronavirus disease (COVID-19) on the enjoyment of all human rights by older persons, A/75/205, 21 July 2020.

86 Report of the Working Group of Experts on People of African Descent - COVID-19, systemic racism and global protests, A/HRC/45/44, 21 August 2020.

87 Report of the Special Rapporteur on the sale and sexual exploitation of children, including child prostitution, child pornography and other child sexual abuse material - Impact of coronavirus disease on different manifestations of sale and sexual exploitation of children, A/HRC/46/31, 22 January 2021.

88 Report of the Special Rapporteur on the rights of indigenous peoples, A/75/185, 20 July 2020.

89 Report of the Special Rapporteur on the elimination of discrimination against persons affected by leprosy and their family members, A/HRC/44/46, 27 April 2020.

90 Report of the Special Rapporteur on contemporary forms of slavery, including its causes and consequences - Impact of the coronavirus disease pandemic on contemporary forms of slavery and slavery-like practices, A/HRC/45/8, 4 August 2020.

91 The respective amount is just a fraction of the estimated 90 billion dollars needed to protect 10 per cent of the world's poorest population from the negative consequences of the COVID-19 pandemic. See: Global Humanitarian Response Plan - COVID-19, United Nations Coordinated Appeal - April-December 2020, July 2020, pp. 4, 16-19. 
needs, such as those related to famine prevention, NGOs, protection of vulnerable people etc. Founded at the initiative of the Inter-Agency Standing Committee (IASC), ${ }^{92}$ it encompasses and combines appeals from an impressive number of United Nations agencies, programmes and funds, primarily the Food and Agriculture Organization (FAO), the International Organisation for Migrations (IOM), the United Nations Development Programme (UNDP), the United Nations Population Fund (UNFPA), the UN-Habitat, the United Nations Refugee Agency (UNHCR), the United Nations International Children's Emergency Fund (UNICEF), the United Nations Relief and Works Agency for Palestine Refugees in the Near East (UNRWA) and the United Nations World Food Programme (WFP). It was also complementary to similar plans, such as the Strategic Preparedness and Response Plan, as well as those of the International Red Cross and Red Crescent Movement. ${ }^{93}$

The Global Humanitarian Response Plan is an overarching and future-oriented endeavour, which integrates the urgent humanitarian response to COVID-19 with the responses to other existing or emerging humanitarian crises (e.g. wars and natural disasters), all that with a view to creating a more sustainable humanitarian system. All the actions performed within the Plan's ambit contribute to at least one of the three strategic priorities: "1. containing the spread of COVID-19 and decreasing morbidity and mortality; 2 . decreasing the deterioration of human assets and rights, social cohesion and livelihoods; and 3. protecting, assisting and advocating for refugees, internally displaced persons, migrants and host communities particularly vulnerable to the pandemic." 94 The Plan carefully considers both the public health impact and the socio-economic impact of COVID-19. Along the way, particularly vulnerable people - women and girls, persons with disabilities, older persons, children, adolescents and youth, refugees, asylum-seekers, IDPs and migrants, food-insecure people and informal urban settlement dwellers - were regularly in the Plan's spotlight.

Substantial humanitarian measures require substantial funding. ${ }^{95}$ The main funding sources of the Global Humanitarian Response Plan have been Governments' budgets and the European Commission. Namely, in 2020, the top five donors

92 The Inter-Agency Standing Committee (IASC) was established by the United Nations General Assembly resolution 46/182 in 1991 as a body responsible for contributing to the humanitarian emergency assistance provided by the United Nations. Nowadays, the IASC is "the longest-standing and highestlevel humanitarian coordination forum of the UN system". See: Strengthening of the coordination of humanitarian emergency assistance of the United Nations, A/RES/46/182, 19 December 1991.

93 Global Humanitarian Response Plan - COVID-19, op. cit., note 91, pp. 4, 12.

$94 \quad$ Ibid., pp. 12, 23-63.

95 A graphic overview of the array of universal COVID-19 Response Plans see in: Ibid., p. 97. 
were the USA, Germany, the European Commission, the United Kingdom and Japan while the most supported individual countries were Syrian Arab Republic, Yemen, Lebanon and South Sudan. ${ }^{96}$ However, regardless of all the efforts to secure adequate funding, the gap between urgent humanitarian needs and funding received remains wide. ${ }^{97}$

\section{b) Strategic Preparedness and Response Plan (SPRP)}

Initiated by the World Health Organisation (WHO) and partners in February 2020, the Strategic Preparedness and Response Plan is a global health response designed to address urgent health needs around the globe. It represents one of the most urgent United Nations initiatives given the fact that it was adopted only four days after the WHO's Director-General declared COVID-19 "a public health emergency of international concern (PHEIC)", i.e. the WHO's highest level of alarm under international law. ${ }^{98}$

Since the thematic focus of the Strategic Preparedness and Response Plan is much more limited than the focus of the Global Humanitarian Response Plan, so is its funding. The overall financial envelope is estimated at 1.74 billion dollars and those funds are directed to the implementation of public health measures necessary to respond effectively to the COVID-19 pandemic. The main funders of the Plan are Governments' budgets, the UN Central Emergency Response Fund (CERF) and WHO's Solidarity Response Fund. ${ }^{99}$ Unlike the thematic focus, the geographical scope of the Plan is wider than the one of the Global Humanitarian Response Plan and it encompasses all the countries in the world. The strength of the Plan also lies in the fact that it was launched by, as van Schaik et al. put it, "the only international organisation with a universal mandate for norm-setting on how to handle infectious diseases of global concern". ${ }^{100}$

In 2020, the main goal of this response strategy was to prevent further transmission of COVID-19 and to mitigate a variety of its negative impacts. The urgent measures included three types of mutually interwoven activities - rapid establishment of international cooperation and operational support; increasing country

\footnotetext{
96 Total Reported Funding 2020, [https://fts.unocha.org/global-funding/overview/2020], Accessed 2 March 2021.

${ }_{97}$ For example, only $4.4 \%$ of the funding demanded for urgent humanitarian needs has been donated in 2021. See: Humanitarian Aid Contributions, [https://fts.unocha.org/], Accessed 2 March 2021.

98 COVID-19 Strategic Preparedness and Response Plan, 1 February 2021 - 31 January 2022, World Health Organization, Geneva, 2021, p. viii.

99 United Nations Comprehensive Response to COVID-19, op. cit., note 47, p. 9.

100 Van Schaik ; Jørgensen ; van de Pas, op. cit., note 9, p. 1145.
} 
preparedness and response operations; and acceleration of priority research and innovation related to COVID-19. The Plan foresees a very precise monitoring framework with exact key performance indicators divided into several categories, such as epidemiology situation, country readiness and capacity, global response in terms of programme management, supply and R\&D etc. ${ }^{101}$ Built on the respective monitoring framework and experiences on the ground, the WHO has issued the updated Strategic Preparedness and Response Plan 2021, which translates the knowledge accumulated in 2020 into strategic actions. In that respect, it defines six key strategic public health objectives to fully concentrate on in 2021: suppression of transmission, reduction of exposure, countering misinformation, protecting the vulnerable, reducing mortality and morbidity from all causes, and accelerating equitable access to new COVID-19 tools (e.g. vaccines, diagnostics and therapeutics). ${ }^{102}$

\subsection{United Nations Emergency Financing at the Time of COVID-19}

Given the fact that funding is a building block of the United Nations urgent response to COVID-19, it is useful to wrap this analysis up with a brief overview of the three principal funding mechanisms, i.e. the UN COVID-19 Response and Recovery Fund, the UN Central Emergency Response Fund and the Solidarity Response Fund.

The UN COVID-19 Response and Recovery Fund was launched by the UN Secretary-General to help low- and middle-income countries recover economically and socially sooner and more effectively with the United Nations' stimulus. It was established for the period of two years (April 2020 - April 2022) with the initial financial requirement of 2 billion dollars. ${ }^{103}$ It should be perceived in the light of the UN Secretary- General's Call for Solidarity, which requests global action to stop the COVID-19 pandemic and mitigate its serious consequences. Namely, the Fund should be in line with Call's three objectives: tackling the health emergency; focusing on the social and economic response and recovery; and helping countries recover better. ${ }^{104}$ The funding sources are contributions from donors (Governments, organisations and individuals), investment income from the Fund as well as interest from the Fund and participating organisations. The money is currently directed into more than 200 various investments (protecting people, economic response, social co-

\footnotetext{
101 Novel Coronavirus (2019-nCoV), World Health Organization, Geneva, 4 February 2020, pp. 1, 5-20.

102 COVID-19 Strategic Preparedness and Response Plan, op. cit., note 98, pp. 10, 13-17.

103 The Secretary-General's UN COVID-19 Response and Recovery Fund, United Nations, New York, April 2020, p. 2.

104 Ibid.
} 
hesion, health etc.) while respecting the principles of immediate action, leaving no one behind and inclusion. ${ }^{105}$ The Fund is complementary to the Strategic Preparedness and Response Plan and the Global Humanitarian Response Plan. ${ }^{106}$

The UN Central Emergency Response Fund (CERF) is a UN's funding mechanism with an over 15-year-long tradition of financing urgent humanitarian assistance to people in crisis. Since its establishment by the UN General Assembly in 2005, the Fund has enabled 7 billion dollars of life-saving assistance to over 100 countries. Similar to the UN COVID-19 Response and Recovery Fund, the main donors encompass Governments, corporations, foundations and individuals. The rapid and agile nature of the Fund makes it a perfect complementary tool for responding to the impacts of the pandemic. ${ }^{107}$ With the total allocation of 241 million dollars for the COVID-19 response, the Fund has contributed greatly to covering the expenses of supporting logistics and common services (e.g. transportation of supplies), the health and sanitation response (e.g. providing vulnerable communities with health care and protective equipment) and dealing with the secondary impacts of the pandemic (e.g. distribution of food and cash transfers). This involves providing 58 million dollars to NGOs, the Red Cross and Red Crescent National Societies and other local partners. ${ }^{108}$

The Solidarity Response Fund was set by the World Health Organization (WHO) for the purpose of supporting the work of the $\mathrm{WHO}$ and its partners to help countries "prevent, detect and respond to the COVID-19 pandemic" in a speedy, effective and flexible way. ${ }^{109}$ Its allocation is disbursed in line with the priorities and principles of the Strategic Preparedness and Response Plan. As of March 2021, the Fund's budget amounted to almost 243 million dollars, raised from over 663,000 donors (corporations, foundations, individuals, organizations etc). The funds have been invested in some focal COVID-19-related activities - distributing essential supplies, coordinating global vaccine $\mathrm{R} \& \mathrm{D}$, protecting internally displaced people and refugees, supporting vulnerable people in low-income communities and alleviating negative consequences of the pandemic on youth development. ${ }^{110}$

\footnotetext{
105 For the catalogue of the projects funded by the UN Response and Recovery Fund, funded areas, donors and key priorities see: Global Interim Report of the UN COVID-19 Response and Recovery Fund, UN Multi-Partner Trust Fund Office, New York, 2020.

106 The Secretary-General's UN COVID-19 Response and Recovery Fund, loc. cit., note. 103.

107 See: CERF Annual Results Report 2020, United Nations Office for the Coordination of Humanitarian Affairs (OCHA), New York, 2020, pp. 2-10.

108 More on the UN Central Emergency Response Fund investments see: OCHA Humanitarian Pooled Funds - COVID-19 Response, OCHA, 2 March 2021.

109 COVID-19 Solidarity Response Fund for the World Health Organisation, Impact Report, 1 January - 31 March 2021, WHO, 2021, p. 4.

110 Ibid., pp. 2-3.
} 


\section{CONCLUSION}

The COVID-19 pandemic has radically reshaped our lives and, in consequence, prompted the United Nations and the European Union to flexibly respond to new challenges and refocus their priorities. At the time of the global health emergency, flexibility usually implies urgency. Both the United Nations and the European Union have triggered their urgent mechanisms and inventively resorted either to creating new or using current protection schemes which have enabled them to appropriately cope with the immense human and economic toll.

In order to alleviate the negative socio-economic impact of the COVID-19 pandemic, the European Union has secured cash injections worth billions of euros, which are aimed at the satisfaction of the most pressing health, economic and social needs. Thus, the financial assistance is directed to the most exposed domains such as healthcare, $S M E s$, labour markets, the most deprived, fishermen and farmers etc. Additionally, the European Union has simplified the use of EU funds to the greatest possible extent in an attempt to speedily mobilise Cohesion Policy resources and boost socio-economic recovery. The emphasis is hence put on both the crisis response and crisis repair measures. The introduced and foreseen standards have been longsighted in a sense that they give due diligence to the usual, pre-COVID-19 priorities of the European Union, such as investments in twin green and digital transitions. Like the European Union, the United Nations has also addressed health, socio-economic and recovery aspects of the crisis; however, its prime focus of concern have become humanitarian and human rights conditions. The United Nations has asserted that public health emergencies, such as the COVID-19 pandemic, pose an extreme threat not only to physical, mental and social well-being but also to all human rights - civil, political, economic, social and cultural. Moreover, the United Nations have been much more vocal in warning about the grave consequences of the COVID-19-driven economic downturn for further widening of the gap between the rich and the poor, which may possibly lead to turmoil or outbreaks of civil and world wars.

The United Nations' and the European Union's urgent actions on the ground are fully dependant on adequate sources of financing. Both international organisations have secured those sources through various funding schemes such as targeted funds and initiatives. Nevertheless, the United Nations' numbers are currently more modest and not fully in line with real needs. Since the COVID-19 pandemic is still in full swing, despite all the lockdowns and vaccination efforts, the United Nations and the European Union need to look further for innovative and sustainable urgent responses based on the principles of solidarity, global cooperation, good governance, transparency and equality. The burden is great, yet with the vast experience of these two organisations in emergency responses achievable. 


\section{REFERENCES}

\section{BOOKS AND ARTICLES}

1. Alawa, J. et al., Addressing COVID-19 in Humanitarian Settings: A Call to Action, Conflict and Health, Vol. 14, No. 1, 2020, pp. 1-4

2. Beaussier, A.-L.; Cabane, L., Strengthening the EU's Response Capacity to Health Emergiencies: Insights from EU Crisis Management Mechanisms, European Journal of Risk Regulation, Vol. 11, No. 4, 2020, pp. 808-820

3. Bouhon, F. et al., L'État belge face à la pandémie de Covid-19: esquisse d'un régime d'exception, Courrier hebdomadaire, No. 2446, 2020, pp. 5-40

4. Cormacain, R., Keeping COVID-19 Emergency Legislation Socially Distant from Ordinary Legislation: Principles for the Structure of Emergency Legislation, The Theory and Practice of Legislation, Vol. 8, No. 3, 2020, pp. 245-265

5. Craig, P.; de Búrca, G., EU Law - Text, Cases, and Materials, Oxford University Press, Oxford, 2020

6. De Guttry, A., Is the International Community Ready for the Next Pandemic Wave? A Legal Analysis of the Preparedness Rules Codified in Universal Instruments and of their Impact in the Light of the Covid-19 Experience, Global Iurist, Vol. 20, No. 3, 2020, pp. 1-41

7. Delhomme, V., Emancipating Health from the Internal Market: For a Stronger EU (Legislative) Competence in Public Health, European Journal of Risk Regulation, Vol. 11, No. 4, 2020, pp.747-756

8. Haldon, J. et al., Between Resilience and Adaptation: A Historical Framework for Understanding Stability and Transformation of Societies to Shocks and Stress, in: Linkov, I.; Keenan, J. M.; Trump, B. D. (eds.), COVID-19: Systemic Risk and Resilience, Springer, Cham, 2021, pp. $235-268$

9. Hynes, W. et al., Complexity, Interconnectedness and Resilience: Why a Paradigm Shift in Economics is Needed to Deal with COVID-19 and Future Shocks, in: Linkov, I.; Keenan, J. M.; Trump, B. D. (eds.), COVID-19: Systemic Risk and Resilience, Springer, Cham, 2021, pp. $61-75$

10. Ladi, S.; Tsarouhas, D., EU Economic Governance and COVID-19: Policy Learning and Windows of Opportunity, Journal of European Integration, Vol. 42, No. 8, 2020, pp. 1041-1056

11. Leino, P., The Politics of Efficient Compromise in the Adoption of EU Legal Acts, in: Cremona, M.; Kilpatrick, C., (eds.), EU Legal Acts: Challenges and Transformations, Oxford University Press, Oxford, 2018, pp. 30-70

12. Loewenthal, P.-J., Articles 289-292, in: Kellerbauer, M.; Klamert, M.; Tomkin, J. (eds.), The EU Treaties and the Charter of Fundamental Rights - A Commentary, Oxford University Press, Oxford, 2019, pp. 1911-1933

13. Mazur-Kumrić, N.; Komanovics, A., The Human Rights Council and the Universal Periodic Review: A Novel Method of Promoting Compliance with Human Righs, in: Drinóczi, T. et al. (eds.), Contemporary Legal Challenges: EU - Hungary - Croatia, Faculty of Law, University of Pécs/Faculty of Law, J. J. Strossmayer University of Osijek, 2012, pp. 641-671. 
14. Menoni, S., Enhancing Current Practice from the Natural and Manmade Hazards Domain to Pandemic: Insights from the Italian Case, in: Linkov, I.; Keenan, J. M.; Trump, B. D. (eds.), COVID-19: Systemic Risk and Resilience, Springer, Cham, 2021, pp. 75-103.

15. Meßerschmidt, K., COVID-19 Legislation in the Light of the Precautionary Principle, The Theory and Practice of Legislation, Vol. 8, No. 3, 2020, pp. 267-292

16. Panebianco, S., Towards a Human and Humane Approach? The EU Discourse on Migration Amidst the COVID-19 Crisis, Italian Journal of International Affairs, Vol. 56, No. 2, 2021, pp. 19-37

17. Prata, J. C. et al., COVID-19 Pandemic Repercussions on the Use and Management of Plastics, Environmental Science \& Technology, Vol. 54, No. 13, 2020, pp. 7760-7765

18. Pūras, D. et al., The Right to Health Must Guide Responses to COVID-19, The Lancet, Vol. 395, No. 10241, 2020, pp. 1888-1890

19. Rutkow, L., Origins of the COVID-19 Pandemic and the Path Forward: A Global Public Health Policy Perspective, in: Brands, H.; Gavin, F. J. (eds.), COVID-19 and World Order: The Future of Conflict, Competition, and Cooperation, Johns Hopkins University Press, Baltimore, 2020, pp. 93-113

20. Santos, J.; Pagsuyoin, Sh., The Impact of "Flatten the Curve" on Interdependent Economic Sectors, in: Linkov, I.; Keenan, J. M.; Trump, B. D. (eds.), COVID-19: Systemic Risk and Resilience, Springer, Cham, 2021, pp. 163-181

21. Schütze, R., An Introduction to European Law, Oxford University Press, Oxford, 2020

22. Siders, A. R.; Gerber-Chavez, L., Resilience for Whom? Insights for COVID-19 for Social Equity in Resilience, in: Linkov, I.; Keenan, J. M.; Trump, B. D. (eds.), COVID-19: Systemic Risk and Resilience, Springer, Cham, 2021, pp. 373-389

23. Subedi, S. P., Protection of Human Rights through the Mechanism of UN Special Rapporteurs, Human Rights Quarterly, Vol. 33, No. 1, 2011, pp. 201-228

24. Trump, B. D.; Keenan, J. M.; Linkov, I., Multi-disciplinary Perspectives on Systemic Risk and Resilience in the Time of COVID-19, in: Linkov, I.; Keenan, J. M.; Trump, B. D. (eds.), COVID-19: Systemic Risk and Resilience, Springer, Cham, 2021, pp. 1-11

25. Van Schaik, L.; Jørgensen, K. E.; van de Pas, R., Loyal at Once? The EU's Global Health Awakening in the COVID-19 Pandemic, Journal of European Integration, Vol. 49, No. 8, 2020, pp. 1145-1160

26. Wells, E. M. et al., Real-time Anticipatory Response to COVID-19, A Novel Methodological Approach, in: Linkov, I.; Keenan, J. M.; Trump, B. D. (eds.), COVID-19: Systemic Risk and Resilience, Springer, Cham, 2021, pp. 35-61

27. Wolff, S.; Ladi, S., European Union Responses to the COVID-19 Pandemic: Adaptability in Times of Permanent Emergency, Journal of European Integration, Vol. 42, No. 8, 2020, pp. $1025-1040$

\section{EU LAW}

1. Communication from the Commission 'Coronavirus Response - Using Every Available Euro in Every Way Possible to Protect Lives and Livelihoods', COM (2020) 143 final, Brussels, 2 April 2020. 
2. Communication from the Commission 'Coordinated Economic Response to the COVID-19 Outbreak', COM(2020) 112 final, Brussels, 13 March 2020.

3. Consolidated Version of the Treaty on the Functioning of the European Union, OJ C 202, 7 June 2016.

4. Council Decision of 1 December 2009 adopting the Council's Rules of Procedure, OJ L 325, 11 December 2009.

5. Debates of the European Parliament (Mulder - ELDR, NL), Official Journal of the European Communities, No. 525-527, 9 October 1998.

6. European Council Decision of 1 December 2009 adopting its Rules of Procedure, OJ L 315, 2 December 2009.

7. Proposal for a Regulation of the European Parliament and of the Council amending Regulation (EU) No 1303/2013 and Regulation (EU) No 1301/2013 as regards specific measures to provide exceptional flexibility for the use of the European Structural and Investments Funds in response to the COVID-19 outbreak, COM/2020/138 final, Brussels, 2 April 2020 .

8. Proposal for a Regulation of the European Parliament and of the Council amending Regulation (EU) No 1303/2013, Regulation (EU) No 1301/2013 and Regulation (EU) No $508 / 2014$ as regards specific measures to mobilise investments in the health care systems of the Member States and in other sectors of their economies in response to the COVID-19 outbreak, COM (2020) 113 final, Brussels, 12 March 2020.

9. Proposal for a Regulation of the European Parliament and of the Council amending Council Regulation (EC) No 2012/2002 in order to provide financial assistance to Member States and countries negotiating their accession to the Union seriously affected by a major public health emergency, COM2020 114 final, Brussels, 12 March 2020.

10. Regulation (EU) 2020/2221 of the European Parliament and of the Council of 23 December 2020 amending Regulation (EU) No 1303/2013 as regards additional resources and implementing arrangements to provide assistance for fostering crisis repair in the context of the COVID-19 pandemic and its social consequences and for preparing a green, digital and resilient recovery of the economy (REACT-EU), OJ L 437, 28 December 2020.

11. Rules of Procedures, European Parliament 2019-2024 - $9^{\text {th }}$ Parliamentary Term, European Parliament, January 2021.

\section{UN DOCUMENTS}

1. Code of Conduct for Special Procedures Mandate-holders of the Human Rights Council, A/ HRC/5/21, 7 August 2007.

2. Directory of Special Procedures Mandate Holders, HRC/NONE/2017/74/Rev.3/iPub, July 2020.

3. Impact of the Coronavirus Disease (COVID-19) Pandemic on the Enjoyment of Human Rights Around the World, Including Good Practices and Areas of Concern, A/ HRC/46/19, 18 January 2021.

4. Report of the Special Rapporteur in the field of cultural rights - COVID-19, culture and cultural rights, A/HRC/46/34, 17 February 2021. 
5. Report of the Special Rapporteur on the sale and sexual exploitation of children, including child prostitution, child pornography and other child sexual abuse material - Impact of coronavirus disease on different manifestations of sale and sexual exploitation of children, A/HRC/46/31, 22 January 2021.

6. Report of the Special Rapporteur on the implications for human rights of the environmentally sound management and disposal of hazardous substances and wastes - Duty to prevent exposure to the COVID-19 virus, A/HRC/45/12, 13 October 2020.

7. Report of the Working Group of Experts on People of African Descent - COVID-19, systemic racism and global protests, A/HRC/45/44, 21 August 2020.

8. Report of the Special Rapporteur on contemporary forms of slavery, including its causes and consequences - Impact of the coronavirus disease pandemic on contemporary forms of slavery and slavery-like practices, A/HRC/45/8, 4 August 2020.

9. Report of the Independent Expert on the effects of foreign debt and other related international financial obligations of States on the full enjoyment of all human rights, particularly economic, social and cultural rights - Addressing the COVID-19 Debt related Problems of Developing Countries from a Human Rights perspective, A/75/164, 31 July 2020.

10. Report of the Independent Expert on protection against violence and discrimination based on sexual orientation and gender identity - Violence and discrimination based on sexual orientation and gender identity during the coronavirus disease (COVID-19) pandemic, A/75/258, 28 July 2020.

11. Report of the Special Rapporteur on the right to privacy, A/75/147, 27 July 2020.

12. Report of the Special Rapporteur on adequate housing as a component of the right to an adequate standard of living, and on the right to non-discrimination in this context - COVID-19 and the right to adequate housing: impacts and the way forward, A/75/148, 27 July 2020.

13. Report of the Special Rapporteur on violence against women, its causes and consequences Intersection between the coronavirus disease (COVID-19) pandemic and the pandemic of gender-based violence against women, with a focus on domestic violence and the "peace in the home" initiative, A/75/144, 24 July 2020.

14. Report of the Special Rapporteur on the negative impact of unilateral coercive measures on the enjoyment of human rights - Negative impact of unilateral coercive measures on the enjoyment of human rights in the coronavirus disease pandemic, A/75/209, 21 July 2020.

15. Report of the Independent Expert on the enjoyment of all human rights by older persons - Impact of the coronavirus disease (COVID-19) on the enjoyment of all human rights by older persons, A/75/205, 21 July 2020.

16. Report of the Special Rapporteur on the rights of indigenous peoples, A/75/185, 20 July 2020 .

17. Final report of the Special Rapporteur on the right of everyone to the enjoyment of the highest attainable standard of physical and mental health, A/75/163, 16 July 2020.

18. Report of the Special Rapporteur on the right to education - Right to education: impact of the COVID-19 crisis on the right to education; concerns, challenges and opportunities, A/ HRC/44/39, 15 June 2020. 
19. Report of the Special Rapporteur on the elimination of discrimination against persons affected by leprosy and their family members, A/HRC/44/46, 27 April 2020.

20. Report of the Special Rapporteur on the promotion and protection of the right to freedom of opinion and expression - Disease pandemics and the freedom of opinion and expression, A/HRC/44/49, 23 April 2020.

21. Report to the General Assembly on the Fifth Session of the Council, A/HRC/5/21, 7 August 2007.

22. Review of the Work and Functioning of the Human Rights Council, A/HRC/RES/16/21, 12 April 2011.

23. Strengthening of the coordination of humanitarian emergency assistance of the United Nations, A/RES/46/182, 19 December 1991.

\section{REPORTS AND ANALYSES}

1. CERF Annual Results Report 2020, United Nations Office for the Coordination of Humanitarian Affairs (OCHA), New York, 2020.

2. COVID-19 Solidarity Response Fund for the World Health Organisation, Impact Report, 1 January - 31 March 2021, WHO, 2021.

3. COVID-19 Strategic Preparedness and Response Plan, 1 February 2021 - 31 January 2022, World Health Organization, Geneva, 2021.

4. Global Humanitarian Response Plan - COVID-19, United Nations Coordinated Appeal April-December 2020, July 2020.

5. Global Interim Report of the UN COVID-19 Response and Recovery Fund, UN MultiPartner Trust Fund Office, New York, 2020.

6. Impact of the COVID-19 Pandemic on Trade and Development: Transitioning to a New Normal, UNCTAD/OSG/2020/1, 19 November 2020.

7. Looking Back to Look Ahead: A Rights-based Approach to Social Protection in the PostCOVID-19 Economic Recovery, Special Rapporteur on extreme poverty and human rights, United Nations Human Rights Special Procedures, New York, 11 September 2020.

8. Mandates of the Special Rapporteur on the human rights of migrants et al., UA OTH 87/2020, 15 January 2021.

9. Manual of Operations of the Specific Procedures of the Human Rights Council, Human Rights Council, New York, August 2008.

10. Novel Coronavirus (2019-nCoV), World Health Organization, Geneva, 4 February 2020.

11. OCHA Humanitarian Pooled Funds - COVID-19 Response, OCHA, 2 March 2021.

12. Special Procedures and Covid-19, United Nations Human Rights Special Procedures, New York, 22 January 2021.

13. United Nations Comprehensive Response to COVID-19: Saving Lives, Protecting Societies, Recovering Better, United Nations, New York, September 2020.

14. United Nations Comprehensive Response to COVID-19: Saving Lives, Protecting Societies, Recovering Better, United Nations, New York, June 2020. 
15. What Will be the Impact of the COVID-19 Pandemic on Healthcare Systems?, Deloitte, Paris, June 2020.

16. The Impact of the COVID-19 Pandemic on Jobs and Incomes in G20 Economies, ILOOECD paper prepared at the request of G20 Leaders Saudi Arabia’s G20 Presidency 2020, ILO-OECD, 2020.

17. The Secretary-General's UN COVID-19 Response and Recovery Fund, United Nations, New York, April 2020.

\section{WEBSITE REFERENCES}

1. Current and Former Mandate-Holders for Existing Mandates Valid as of 1 November 2020, [https://www.ohchr.org/EN/HRBodies/SP/Pages/Currentmandateholders.aspx], Accessed 8 February 2021

2. Humanitarian Aid Contributions, [https://fts.unocha.org/], Accessed 2 March 2021

3. REACT-EU, [https://ec.europa.eu/regional_policy/en/newsroom/coronavirus-response/ react-eu], Accessed 8 March 2021

4. Total Reported Funding 2020, [https://fts.unocha.org/global-funding/overview/2020], Accessed 2 March 2021

5. WHO Coronavirus (COVID-19) Dashboard, [https://covid19.who.int/], Accessed 3 April 2021 